\title{
Peripheral CD19+ $B$-cell counts and infusion intervals as a surrogate for long-term B-cell depleting therapy in multiple sclerosis and neuromyelitis optica/neuromyelitis optica spectrum disorders
}

\author{
Gisa Ellrichmann ${ }^{1}$ D . Jan Bolz ${ }^{1} \cdot$ Maren Peschke $^{2} \cdot$ Alexander Duscha $^{1} \cdot$ Kerstin Hellwig $^{1} \cdot$ De-Hyung Lee $^{2}$. \\ Ralf A. Linker ${ }^{2} \cdot$ Ralf Gold $^{1}$ · Aiden Haghikia ${ }^{1}$
}

Received: 10 June 2018 / Revised: 25 September 2018 / Accepted: 10 October 2018 / Published online: 30 October 2018

(C) The Author(s) 2018

\begin{abstract}
Background With ocrelizumab another drug is available for the treatment of multiple sclerosis (MS). Little is known on the long-term use of ocrelizumab on immune cell subsets, and no surrogate markers are available. Rituximab (RTX) has been in off-label use for the treatment of MS, neuromyelitis optica (NMO) and neuromyelitis optica spectrum disorder (NMOSD) for $>10$ years.

Objective We evaluated the long-term depletion and repopulation rate of peripheral CD19 ${ }^{+}$B-cells as a potential surrogate for the clinical outcome, and whether it may serve for dosage and time-to-infusion decision making.

Methods We evaluated the $\mathrm{CD} 19^{+}$and CD $4^{+} / 8^{+}$T-cell counts in $n=153$ patients treated with RTX (132 MS, 21 NMO/ NMOSD). The dosages ranged from 250 to $2000 \mathrm{mg}$ RTX. Depletion/repopulation rates of CD19 ${ }^{+}$B-cells as well as longterm total lymphocyte cell counts, were assessed and corroborated with EDSS, ARR (annualized relapse rate), MRI, and time to reinfusion.

Results CD $19^{+}$B-cells' repopulation rate significantly varied depending on the dosage applied leading to individualized application intervals (mean $9.73 \pm 0.528$ months). Low/absent CD19 ${ }^{+}$B-cell counts were associated with reduced ARR, EDSS, and GD ${ }^{+}$-MRI-lesions. Long-term B-cell-depleting therapy led to a transiently skewed $\mathrm{CD}^{+} / 8^{+} \mathrm{T}^{-}$-ell ratio due to reduced $\mathrm{CD}^{+}{ }^{+}$-cells and absolute lymphocyte counts, which recovered after the second cycle.

Conclusion Our data suggest that $\mathrm{CD} 19^{+}$B-cell repopulation latency may serve as surrogate marker for individualized treatment strategies in MS and NMO/NMOSD, which proved clinically equally effective in our cohort as evaluated by previous studies.
\end{abstract}

Keywords Multiple sclerosis $\cdot$ Neuromyelitis optica $\cdot$ Neuromyelitis optica spectrum disorders $\cdot$ Monoclonal anti-CD20 antibody $\cdot$ CD $19^{+}$B-cell counts

Gisa Ellrichmann and Jan Bolz contributed equally as first authors.

Ralf Gold and Aiden Haghikia contributed equally as senior authors.

Ralf Gold

ralf.gold@rub.de

1 Department of Neurology, St. Josef-Hospital, RuhrUniversity Bochum, Gudrunstrasse 56, 44791 Bochum, Germany

2 Department of Neurology, Friedrich-Alexander-University Erlangen, 91054 Erlangen, Germany

\section{Introduction}

Although the T-cell (Th1 and Th17) mediated pathogenesis of MS is well established, B-cells and the humoral immune involvement are also increasingly recognized as drivers of the autoimmune disease and the concomitant neurodegeneration [18]. Hence, therapies either exclusively targeting B-cells, such as rituximab, ocrelizumab, and ofatumumab, or B-cells along with T-cells, such as alemtuzumab have proven to be effective in clinical trials [6].

The recent approval of the humanized antibody ocrelizumab depleting CD20 ${ }^{+}$B-cells, based on its efficacy shown in two phase III clinical trials in relapsing-remitting MS (RRMS; OPERA I and II studies) and one in 
primary progressive MS (PPMS; ORATORIO study), led to more than ten compounds (nine substance classes) for the treatment of MS [7, 8, 11]. However, the principle of B-cell depletion with its predecessor rituximab (RTX) - a chimeric monoclonal anti-CD20 antibody that binds to cell surface CD20 and induces antibody dependent cell-mediated cytotoxicity - has long been off-label use in MS and other autoimmune disorders. Several phase II studies and case series have previously shown its efficacy in MS $[8,9]$. More recently, retrospective studies analyzing large Swedish MS cohorts receiving RTX treatment for a mean time of $\sim 22$ months provided further evidence for its beneficial therapeutic effect in RRMS and progressive MS [16, 17]. The rapid onset of its therapeutic effect, as shown in MRI measures after RTX initiation suggests that the mechanism by which RTX exerts its therapeutic effects is based not only on depleting B-cells as potential antibody producing cells, but also their involvement in T-cell activation [2]. In addition to MS, RTX has lately proven effective in NMOSD, another autoimmune demyelinating disease of the central nervous system that in contrast to MS is mediated by antibodies directed to the astrocytic aquaporin-4 [12].

Using ocrelizumab, the re-dosing is carried out at a fixed interval and dosage (600 mg every 6 months). Unlike ocrelizumab, there is no standard protocol for RTX infusions. At our centers, it is a current mode of clinical practice to follow B-cell counts as a measure of RTX reinfusion.

The aim of our study was to evaluate repopulation rate of peripheral $\mathrm{CD} 19^{+} \mathrm{B}$-cells, as well as other lymphocyte subtypes as a potential surrogate marker for individual application intervals in patients with MS and NMO/NMOSD treated with RTX.

\section{Patients and methods}

\section{Study population}

The study was approved by the local ethics committees (regno 4493-12), and was intended to identify biological surrogate markers for the efficacy of drugs in $\mathrm{MS}$ and $\mathrm{NMO} /$ NMOSD. For analyses of CD56 ${ }^{+}$NK-cells and Th1-cells in healthy controls and RRMS patients, ethical permit was approved by the local ethics committees (reg-no 15-5351).

Patients who had received RTX and fulfilling either the McDonald criteria for MS or the criteria proposed by Wingerchuk et al. for NMO/NMOSD were included into the study $[14,19]$. RTX was administrated when other options where exhausted or MRI indicated a B-cell pathology. The dosage and application interval was generally based on B-cell repopulation $(2-5 \%)$, but did not follow a standardized protocol and differed on timing of patients' clinic visits, underlying disease activity, side effects, patients' conditions and physicians' decision. That is the reason, why patients' clinical visit intervals and applied RTX dose might vary in a single patient. In general, earlier $(\sim 10$ years ago) the RTX dosages were higher and resembled protocols used by oncologists for the treatment of lymphoma patients. All RTX doses up to $1000 \mathrm{mg}$ were applied in a single infusion, higher doses were given equally distributed within a 2-week interval. Beside this protocol, no double-dosing was administrated. For inclusion treatment should at least be once between April 2006 and September 2016. For baseline data, the EDSS and MRI before the first RTX infusion were used. Patients were treated as in- or out-patients in two German MS centers (Department of Neurology of the St. Josef-Hospital, Ruhr-University Bochum and the Department of Neurology, Friedrich-Alexander-University Erlangen). Anonymized patients' data were used for stratification analyses, i.e. treatment response.

\section{Blood sampling and flow cytometry}

Blood was taken at least twice in every patient in $3.5-\mathrm{ml}$ EDTA tubes (Kabe, Germany) and a total of 893 blood tests were available. For absolute lymphocyte counts, samples were processed within $3 \mathrm{~h}$ and for flow cytometry $\left(\mathrm{CD} 19^{+}\right.$, $\mathrm{CD}^{+}, \mathrm{CD}^{+}$) at least within $24 \mathrm{~h}$. B-cells were represented by CD $19^{+}$B-cells. Reagents used: eBioscience: BD Multitest $^{\mathrm{TM}}$ Truecount CD3/CD16 ${ }^{+} \mathrm{CD} 56 / \mathrm{CD} 45 / \mathrm{CD} 19$; reagent contains FITC-labeled CD3, clone SK7; PE-labeled CD16, clone B73.1, and PE-labeled CD56, clone NCAM 16.2 PerCP-labeled CD45, clone 2D1 (HLe-1); and APC-labeled CD19, clone SJ25C1.

For T-, NK-, B-, and Th1-cells, whole blood cells were stained by BD Multitest ${ }^{\mathrm{TM}}$ 6-Color TBNK Truecount $(\alpha \mathrm{CD} 3$-FITC; $\alpha \mathrm{CD} 16-\mathrm{PE}+\alpha \mathrm{CD} 56-\mathrm{PE} ; \alpha \mathrm{CD} 45-\mathrm{PerCP}$

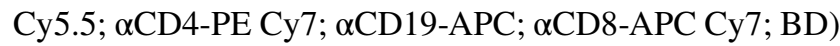
and afterwards analyzed in respect to absolute cell count numbers. Th1-cells were investigated after $4 \mathrm{~h}$ of restimulation with $50 \mathrm{ng} / \mathrm{ml}$ PMA and $1 \mu \mathrm{g} / \mathrm{ml}$ Ionomycin (both Sigma-Aldrich) and inhibition of vesicular transport by $1 \mu \mathrm{g} /$ $\mathrm{ml}$ Monensin via the extracellular staining of whole blood cells with $\alpha$ CD4-FITC (RPA-T4; BD) and intracellular with $\alpha$-IFN $\gamma$-APC (B27; BD) by usage of Foxp3/Transcription Factor Staining Buffer Set (eBioscience). For Treg analysis, cells were stained with CD4-FITC (RPA-T4, eBioscience) and PE Cy7 CD25-APC (BC96, eBioscience) extracellular and FoxP3-PE (236A/E7, eBioscience) intracellular by usage of Foxp3/Transcription Factor Staining Buffer Set (eBioscience) according to manufacturers' protocol. For absolute cell numbers, cell counts of $\mathrm{CD}^{+} \mathrm{IFN} \gamma^{+}$-as well as $\mathrm{CD} 4^{+} \mathrm{CD} 25^{+} \mathrm{FoxP}^{+}$cells were used from FACS Diva v6 analysis. Lysis of erythrocytes in all samples was accomplished using FACS Lysing Solution (BD). For each sample, 5000 total events were recorded for analysis. All 
phenotyping experiments were performed on BD FACS Canto2 (BD Bioscience, Heidelberg) and analyzed by BD FACS DIVA v6 or BD FACS CANTO2/3 software.

\section{Stratification}

The respective absolute long-term lymphocyte cell counts (cells/ $\mu \mathrm{l})$ were corroborated with disability progression (EDSS), MRI and ARR (annualized relapse rate). A relapse was defined as a worsening of clinical symptoms that lasted longer than $24 \mathrm{~h}$ and was not related to any infectious disease. We recorded the change in number of T1and T2-weighed lesions as well as numbers of gadolinium enhancing $\left(\mathrm{GD}^{+}\right) \mathrm{T} 1$-lesions. EDSS, cerebral and spinal MRI compared to baseline were assessed before RTX therapy and after 12, 24 and 36 months.

\section{Statistics}

Statistical analyses were performed using GraphPad Prism 6.0. Data are presented as a mean \pm standard deviation (SD). For statistical analysis, group differences were evaluated using one-way analysis of variance (ANOVA) followed by Bonferroni's post-hoc test (GraphPad Prism 6.0 software, San Diego, CA, USA). The probability levels of $p^{*} \leq 0.05$, $p^{* *} \leq 0.01$, and $p^{* * *} \leq 0.001$ were considered statistically significant for all statistical tests.

\section{Results}

\section{Patients' characteristics and treatment}

A total of 153 patients treated with at least one course of B-cell depleting RTX therapy were included in our study (Table 1). Data of $21 \mathrm{NMO/NMOSD} \mathrm{patients} \mathrm{and} 132$ MS patients were analyzed. 72 of the MS patients were diagnosed as RRMS and 60 of them as secondary progressive MS (SPMS). Mean age of patients at disease onset was $33.58 \pm 11.97$ years and mean age at first RTX infusion was $41.69 \pm 12.35$ years. Mean follow-up was $26.28 \pm 21.08$ months. Mean RTX dose per treatment course was $717 \mathrm{mg} \pm 456$ taking every infusion into account. If RTX infusion within a 2-week interval is regarded as one cycle, mean RTX dose is higher ( $828 \mathrm{mg} \pm 589$ ) (Table 2). We did not observe differences in treatment response or dosing depending on previous therapy. As there would be too many subgroups resulting in small patient numbers per group, we decided to forego those subanalyses concerning pre-treatment.
Table 1 Patients' characteristics

\begin{tabular}{|c|c|c|}
\hline & $n(\%)$ & Mean \pm SD \\
\hline Number of patients & $153(100)$ & \\
\hline Gender (female) & $92(62.4)$ & \\
\hline $\begin{array}{l}\text { Disease duration (years) at first RTX } \\
\text { infusion }\end{array}$ & & $8.17 \pm 8.02$ \\
\hline Mean age (years) at disease onset & & $33.58 \pm 11.97$ \\
\hline Mean age (years) at first RTX infusion & & $41.69 \pm 12.35$ \\
\hline Follow-up (months) & & $26.28 \pm 21.08$ \\
\hline RRMS & $72(45.9)$ & \\
\hline Gender (female) & $50(69.5)$ & \\
\hline $\begin{array}{l}\text { Disease duration (years) at first RTX } \\
\text { infusion }\end{array}$ & & $6.38 \pm 5.89$ \\
\hline Mean age (years) at first RTX infusion & & $36.56 \pm 9.49$ \\
\hline Follow-up (months) & & $24.28 \pm 19.52$ \\
\hline SPMS & $60(38.2)$ & \\
\hline Gender (female) & $28(46.6)$ & \\
\hline $\begin{array}{l}\text { Disease duration (years) at first RTX } \\
\text { infusion }\end{array}$ & & $12.93 \pm 9.71$ \\
\hline Mean age (years) at first RTX infusion & & $45.93 \pm 10.81$ \\
\hline Follow-up (months) & & $28.02 \pm 23.97$ \\
\hline Patients with relapses in SPMS & $26(43.3)$ & \\
\hline NMO/NMOSD & $21(13.3)$ & \\
\hline Gender (female) & $14(66.7)$ & \\
\hline $\begin{array}{l}\text { Disease duration (years) at first RTX } \\
\text { infusion }\end{array}$ & & $3.09 \pm 4.72$ \\
\hline Mean age (years) at first RTX infusion & & $44.24 \pm 17.11$ \\
\hline Follow-up (months) & & $30.81 \pm 19.13$ \\
\hline
\end{tabular}

\section{Cell population}

Of 153 patients evaluated, 112 had a CD19 ${ }^{+}$B-cell count available at baseline (mean $248.3 \pm 230.8$ cells $/ \mu \mathrm{l}$ ). Compared to baseline there was a depletion of $\mathrm{CD} 19^{+} \mathrm{B}$-cells to $4.33 \pm 30.8$ cells $/ \mu \mathrm{l}$ (available counts $n=117$ ) 3 months after first RTX application. CD19 ${ }^{+}$B-cells then increased to $39.66 \pm 71.15$ cells $/ \mu \mathrm{l}(n=58)$ within 6 months and to $54.91 \pm 70.51$ cells $/ \mu \mathrm{l}(n=39)$ after 9 months (Fig. 1a).

The mean number of $\mathrm{CD} 19^{+} \mathrm{B}$-cells before the second RTX infusion was $72.47 \pm 79.63$ cells $/ \mu \mathrm{l}(n=98)$. Three months after the second cycle, a mean of $16.17 \pm 51.18$ $\mathrm{CD} 19^{+} \mathrm{B}$-cells/ $\mu \mathrm{l}(n=77)$ was observed. Cells increased to $41.85 \pm 70.55$ cells $/ \mu \mathrm{l}$ after 9 months $(n=44)$.

Number of CD $19^{+}$B-cells after the third cycle of RTX was similar to the second cycle $(68.87 \pm 75.08$ cells $/ \mu \mathrm{l}$; $n=79)$. CD $19^{+} \mathrm{B}$-cells were still largely diminished after 3 months $(6.38 \pm 25.85$ cells $/ \mu 1 ; n=55)$ and the amount of $\mathrm{CD} 19^{+} \mathrm{B}$-cells at the following time points did not significantly differ compared to the second therapy cycle (6 months: $25.85 \pm 55.12$ cells $/ \mu \mathrm{l} ; n=39,9$ months: $36.65 \pm 64.63$ cells/ $\mu \mathrm{l} ; n=29$ ) (Fig. 1a). The course of $\mathrm{CD} 19^{+} \mathrm{B}$-cells during the whole follow-up is shown in Fig. 1b. 
Table 2 Dosage and application intervals

\begin{tabular}{|c|c|c|}
\hline & $n=(\%)$ & $\begin{array}{l}\text { Application } \\
\text { intervals } \\
\text { (months) }\end{array}$ \\
\hline \multicolumn{3}{|l|}{ All patients } \\
\hline \multicolumn{3}{|l|}{ Number of RTX infusions } \\
\hline 1 st course & 153 & \\
\hline 2 nd course & 130 & $9.7 \pm 4.5$ \\
\hline 3rd course & 93 & $9.8 \pm 5.2$ \\
\hline During whole follow-up & 521 & $9.7 \pm 4.72$ \\
\hline \multicolumn{3}{|l|}{ Single RTX dosage (mg) } \\
\hline 250 & $98(18.8)$ & $6.4 \pm 2.1$ \\
\hline 500 & 207 (39.7) & $9.1 \pm 4.4$ \\
\hline 1000 & $153(29.4)$ & $14.7 \pm 6.7$ \\
\hline$>1000$ & $63(12.1)$ & $11.4 \pm 2.0$ \\
\hline \multicolumn{3}{|l|}{ RRMS } \\
\hline \multicolumn{3}{|l|}{ Number of RTX infusions } \\
\hline 1st course & 72 & \\
\hline 2nd course & 59 & \\
\hline 3rd course & 47 & \\
\hline During whole follow-up & 269 & \\
\hline \multicolumn{3}{|l|}{ Single RTX dosage (mg) } \\
\hline 250 & $60(22.3)$ & $6.4 \pm 2.6$ \\
\hline 500 & $110(40.9)$ & $8.7 \pm 3.7$ \\
\hline 1000 & $62(23.0)$ & $14.3 \pm 6.5$ \\
\hline$>1000$ & $37(13.8)$ & $11 \pm 3.1$ \\
\hline \multicolumn{3}{|l|}{ SPMS } \\
\hline \multicolumn{3}{|l|}{ Number of RTX infusions } \\
\hline 1 st course & 60 & \\
\hline 2nd course & 54 & \\
\hline 3rd course & 29 & \\
\hline During whole follow-up & 187 & \\
\hline \multicolumn{3}{|l|}{ Single RTX dosage (mg) } \\
\hline 250 & $38(20.3)$ & $7.2 \pm 2.6$ \\
\hline 500 & $97(51.9)$ & $9.3 \pm 3.4$ \\
\hline 1000 & $43(23.0)$ & $13 \pm 7.4$ \\
\hline$>1000$ & $9(4.8)$ & $11 \pm 9.3$ \\
\hline \multicolumn{3}{|l|}{ NMO/NMOSD } \\
\hline \multicolumn{3}{|l|}{ Number of RTX infusions } \\
\hline 1 st course & 21 & \\
\hline 2nd course & 17 & \\
\hline 3rd course & 17 & \\
\hline During whole follow-up & 65 & \\
\hline \multicolumn{3}{|l|}{ Single RTX dosage (mg) } \\
\hline 1000 & $48(73.8)$ & $7.2 \pm 3.5$ \\
\hline$>1000$ & $17(26.2)$ & $9.5 \pm 3.7$ \\
\hline
\end{tabular}

Data are expressed as mean \pm SD where appropriate

$n$ number of patients, $N M O$ neuromyelitis optica, $N M O S D$ neuromyelitis optica spectrum disease, RRMS relapsing-remitting MS, RTX rituximab, SPMS secondary progressive MS
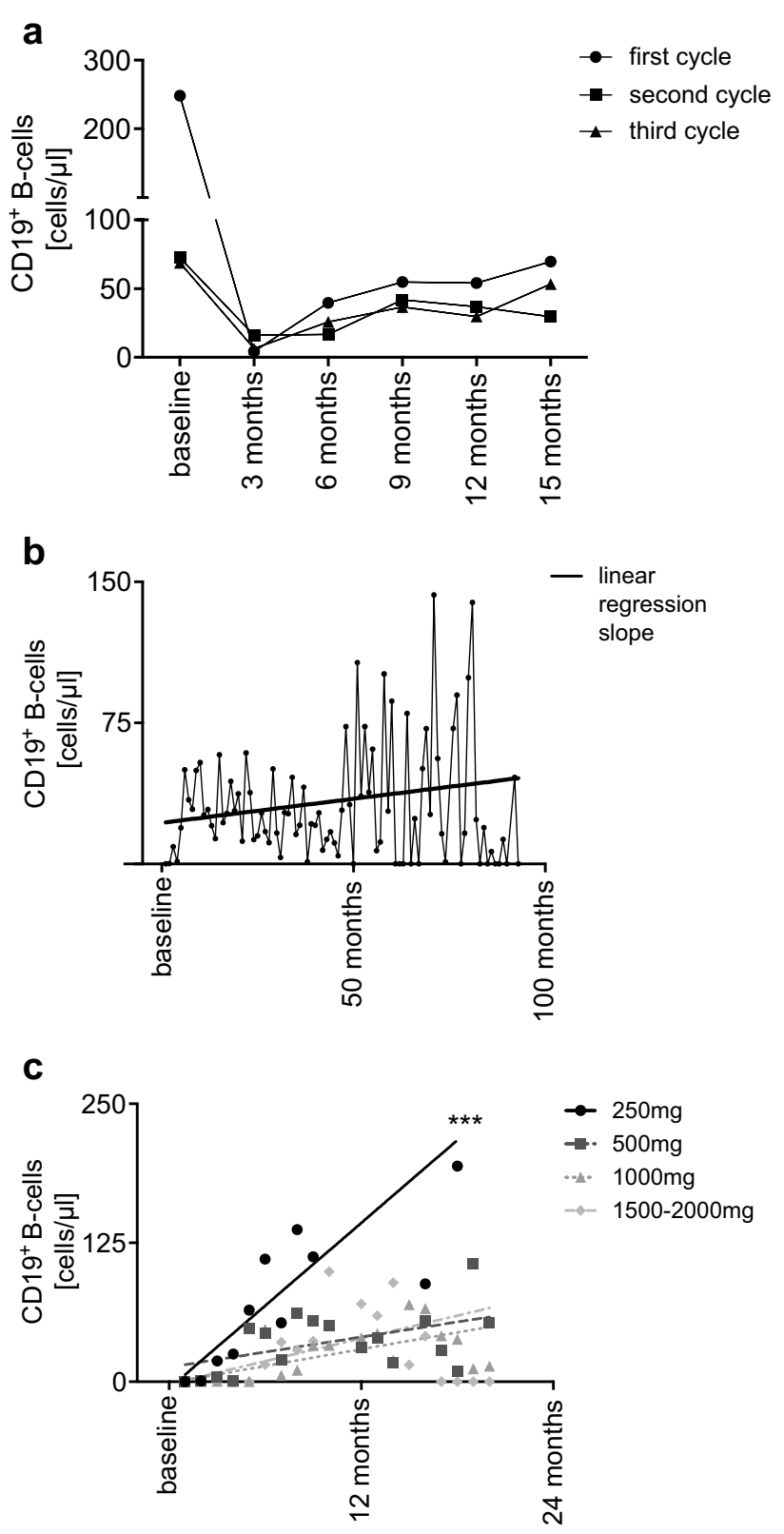

Fig. 1 a Mean absolute cell count (cells/ $\mu$ l) of $\mathrm{CD} 19^{+}$B-cells over time and over multiple cycles of rituximab (RTX). Baseline represents the last available cell count before each cycle of RTX. Cell counts are summarized in 3 months intervals. b Mean absolute cell count (cells $/ \mu \mathrm{l})$ of $\mathrm{CD} 19^{+}$B-cells over time during whole follow-up after the first depletion with RTX. Linear regression slope of mean $\mathrm{CD} 19^{+} \mathrm{B}$-cell counts during therapy. The regression slope slightly increases over time due to reconstitution of $\mathrm{CD} 19^{+} \mathrm{B}$-cell after depletion and decreasing number of patients with redosing. For the decreasing number of patients during follow-up, the graph of mean $\mathrm{CD} 19^{+} \mathrm{B}$-cells shows higher variance as time progresses. c Linear regression of absolute cell count (cells/ $\mu \mathrm{l})$ of $\mathrm{CD} 19^{+} \mathrm{B}$-cells, over multiple cycles of RTX, according to applied dosage

Recovery of CD $19^{+}$B-cells according to dosage was analyzed by linear regression. Patients who received low dose RTX $(250 \mathrm{mg})$ had a significantly faster recovery 
Table 3 Patients' characteristics according to rituximab dosage

\begin{tabular}{|c|c|c|c|c|}
\hline & $250 \mathrm{mg}$ RTX & $500 \mathrm{mg}$ RTX & 1000 mg RTX & $\begin{array}{l}>1000 \mathrm{mg} \\
\text { RTX }\end{array}$ \\
\hline Number of patients & 23 & 47 & 36 & 47 \\
\hline Gender (female) & 18 & 26 & 21 & 27 \\
\hline Mean age (years) at first RTX infusion & $33 \pm 10$ & $48 \pm 12$ & $35 \pm 10$ & $40 \pm 11$ \\
\hline RRMS & 14 & 26 & 17 & 15 \\
\hline SPMS & 9 & 21 & 10 & 20 \\
\hline NMO/NMOSD & - & - & 9 & 12 \\
\hline \multicolumn{5}{|l|}{ Previous treatment } \\
\hline \multicolumn{5}{|l|}{ Mitoxantrone } \\
\hline RRMS & 1 & 13 & 6 & 10 \\
\hline SPMS & 1 & 3 & 1 & - \\
\hline NMO/NMOSD & - & 10 & 5 & 10 \\
\hline \multicolumn{5}{|l|}{ Natalizumab } \\
\hline RRMS & 6 & 9 & 5 & 11 \\
\hline SPMS & 6 & 9 & 5 & 11 \\
\hline NMO/NMOSD & - & - & - & - \\
\hline \multicolumn{5}{|l|}{ DMF } \\
\hline RRMS & 4 & 9 & 1 & - \\
\hline SPMS & 2 & 2 & - & - \\
\hline NMO/NMOSD & 2 & 7 & 1 & - \\
\hline \multicolumn{5}{|l|}{ Azathioprine } \\
\hline RRMS & - & - & 6 & 12 \\
\hline SPMS & - & - & - & - \\
\hline NMO/NMOSD & - & - & 6 & 12 \\
\hline \multicolumn{5}{|l|}{ Cyclophosphamide } \\
\hline RRMS & - & - & 1 & 2 \\
\hline SPMS & - & - & - & - \\
\hline NMO/NMOSD & - & - & 1 & 2 \\
\hline \multicolumn{5}{|l|}{ Glatiramer acetate } \\
\hline RRMS & & 2 & 1 & 2 \\
\hline SPMS & & 1 & 1 & 1 \\
\hline NMO/NMOSD & & 1 & & 1 \\
\hline \multicolumn{5}{|l|}{$\beta$-Interferon } \\
\hline RRMS & 1 & 5 & 10 & 7 \\
\hline SPMS & 1 & 3 & 3 & 4 \\
\hline NMO/NMOSD & & 2 & 7 & 3 \\
\hline \multicolumn{5}{|l|}{ Fingolimod } \\
\hline RRMS & 8 & 6 & 6 & 2 \\
\hline SPMS & 3 & 4 & 2 & 1 \\
\hline NMO/NMOSD & 5 & 2 & 4 & 1 \\
\hline \multicolumn{5}{|l|}{ Alemtuzumab } \\
\hline RRMS & 1 & - & - & 1 \\
\hline SPMS & 1 & - & - & 1 \\
\hline NMO/NMOSD & - & - & - & - \\
\hline \multicolumn{5}{|l|}{ Cladribine } \\
\hline RRMS & 1 & - & - & - \\
\hline SPMS & 1 & - & - & - \\
\hline NMO/NMOSD & - & - & - & - \\
\hline \multicolumn{5}{|l|}{ None } \\
\hline RRMS & - & 2 & - & - \\
\hline SPMS & - & 2 & - & - \\
\hline NMO/NMOSD & - & - & - & - \\
\hline
\end{tabular}

All doses till $1000 \mathrm{mg}$ were given as a single infusion. Doses above were given equally distributed within a 2-week interval 
of CD19 ${ }^{+} \mathrm{B}$-cells compared to $500 \mathrm{mg}$ and higher doses ( $p^{* * *}<0.0001 ; 250 \mathrm{mg}: 12.41 \pm 3.34 \mathrm{CD} 19^{+} \mathrm{B}$-cells/ month, $500 \mathrm{mg}: 2.26 \pm 0.856,1000 \mathrm{mg}: 2.52 \pm 0,455$, 1500-2000 mg 3.42 \pm 0.794 ) (Fig. 1c). Baseline characteristics of different dose groups are given in Table 3.

The interval until the next infusion was significantly shorter in patients who were treated with $250 \mathrm{mg}$ or $500 \mathrm{mg}$ $\operatorname{RTX}\left(p^{* * *}<0.001\right)$ than in patients treated with a higher dose of RTX $\geq 1000 \mathrm{mg}$ ( $250 \mathrm{mg}$ : 6.4 months $\pm 2.1,500 \mathrm{mg}$ : 9.1 months $\pm 4.4,1500-2000 \mathrm{mg}$ : 11.4 months \pm 2.0 ). Application of $1000 \mathrm{mg}$ RTX yielded the longest interval before reinfusion (mean 14.7 months \pm 6.6 ) (Fig. 2a). B-cells at reinfusion where higher in patients treated with lower dosage but the differences were not significant $(250 \mathrm{mg}$ : $92.73 \pm 105.20$ cells $/ \mu \mathrm{l} ; 500 \mathrm{mg}$ : $81.24 \pm 73.99 \mathrm{cells} / \mu \mathrm{l} ; 1000 \mathrm{mg} 54.55 \pm 65.92 \mathrm{cells} / \mu \mathrm{l}$; 1500-2000 mg: $69.05 \pm 77.24$ cells $/ \mu \mathrm{l})$.

a
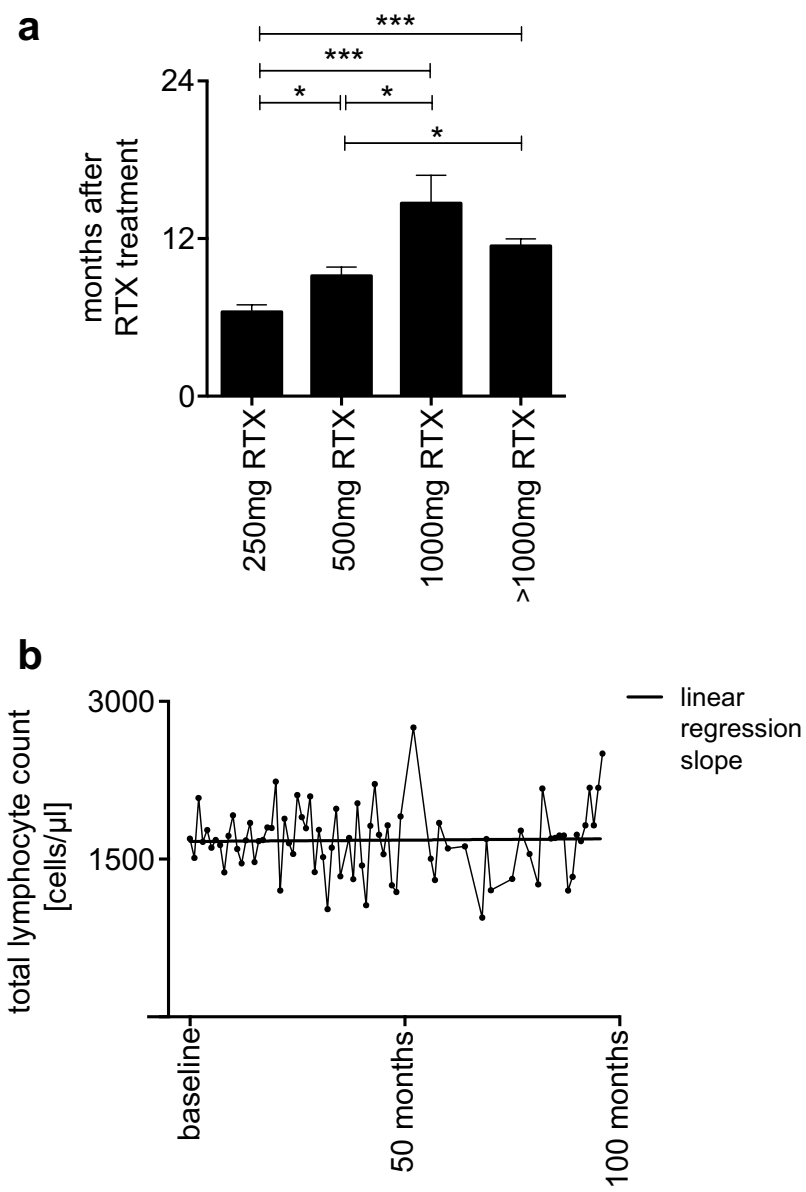

Fig. 2 a Re-dosing intervals according to dosage (error bars represent SEM). b Mean total lymphocyte count (cells/ $\mu \mathrm{l})$ over time during whole follow-up after the first depletion with rituximab (RTX). To identify and determine the total counts of lymphocytes in the peripheral blood, flow cytometric methods were used. Linear regression slope of mean cell counts
Patients diagnosed with NMO/NMOSD generally received higher dosages $(1194 \pm 369 \mathrm{mg})$ of RTX than patients diagnosed with MS $\left(824 \pm 824 \mathrm{mg} ; p^{* * *}<0.0001\right)$ in shorter intervals $(7.7 \pm 4.3$ months vs. $9.4 \pm 4.2$ months, $p=0.008)$ and tended to have slower recovery of B-cells per month (MS 4.02 cells $/ \mu \mathrm{l} /$ months $\pm 2.65, \mathrm{NMO} / \mathrm{NMOSD}$ $3.69 \mathrm{cells} / \mu \mathrm{l} / \mathrm{months} \pm 5.89 ; p=0.0685)$.

Our long-term observation of total lymphocyte count over 100 months showed constant amount of cells over time (Fig. 2b). Number of CD $4^{+}$-cells (Fig. 3a) and CD8 ${ }^{+}$ -cells (Fig. 3b) as well as NK-cells (Fig. 3c) only slightly varied during application interval. $\mathrm{CD} 4^{+} / \mathrm{CD}^{+}$ratio did not significantly change over time (Fig. 3d).

In a sub-population $(n=25), \mathrm{CD} 56^{+} \mathrm{NK}-$, Treg- and Th1-cells were evaluated (Fig. 4a-c). NK-cells were normalized under RTX treatment and were lower in RRMS as compared with controls. Blood samples were obtained at remission. RRMS group was treated with dimethyl fumarate, detailed characteristics of the different groups are given in Table 4.

\section{Clinical course and MRI}

Less than $40 \%$ (28/72) of patients with relapsing forms of MS and one-third (7/21) of the NMO/NMOSD patients had a relapse during the observation period. ARR in our MS cohort significantly decreased from $1.55 \pm 1.362$ years before RTX treatment to $0.26 \pm 0.52$ during follow-up (83\% reduction, $p^{* * *}<0.0001$ ) (Table 5). ARR in NMO/ NMOSD patients decreased from $2.22 \pm 1.89$ to $0.42 \pm 0.56$ ( $81 \%$ reduction, $p^{* * *}<0.0001$ ). In patients with relapse under RTX average time until first relapse after last infusion was 5.35 \pm 3.04 months (Table 5). There was no correlation between B-cell counts at the time-point of reinfusion and clinical course in patients with relapses.

One year after first application of RTX, 130 EDSS of the 132 MS patients were available for analyses. 32 MS patients improved, 75 remained stable, and 23 worsened (Table 6). 24/36 months after first treatment 101/77 follow-ups were available. 21/21 MS patients had a better score compared to baseline, $45 / 30$ patients did not change and in 20/16 patients a progression of EDSS was documented (Fig. 5a; Table 6). In patients diagnosed with NMO/NMOSD 6 improved, 12 remained stable and in 3 patients a progress in EDSS was documented. At 24/36 months, 15/10 EDSS were available 4/2 improved, 6/4 remained stable and 5/4 had a higher EDSS compared to baseline.

Cerebral MRI scans at baseline were available for 150 patients $(98 \%)$. The number of patients with $\mathrm{Gd}^{+}$lesions significantly decreased during therapy $\left(p^{* * *}<0.001\right)$ from 31 at baseline to 5 at 12 months after treatment. Analyzing spinal MRI, number of patients with $\mathrm{Gd}^{+}$lesions decreased from 35 at baseline to 2 at 12 months $\left(p^{* * *}<0.001\right)$. In 
Fig. 3 a-d Mean absolute cell count (cells/ $\mu \mathrm{l})$ of $\mathrm{T}-\left(\mathrm{CD} 4^{+}\right.$, $\left.\mathrm{CD}^{+}, \mathrm{CD} 4^{+} / \mathrm{CD}^{+}\right)$and natural killer- (NK-) cells $\left(\mathrm{CD} 56^{+} \mathrm{CD} 16^{+}\right)$. Baseline represents the last available cell count before each cycle of rituximab. Cell counts are summarized in 3-month intervals
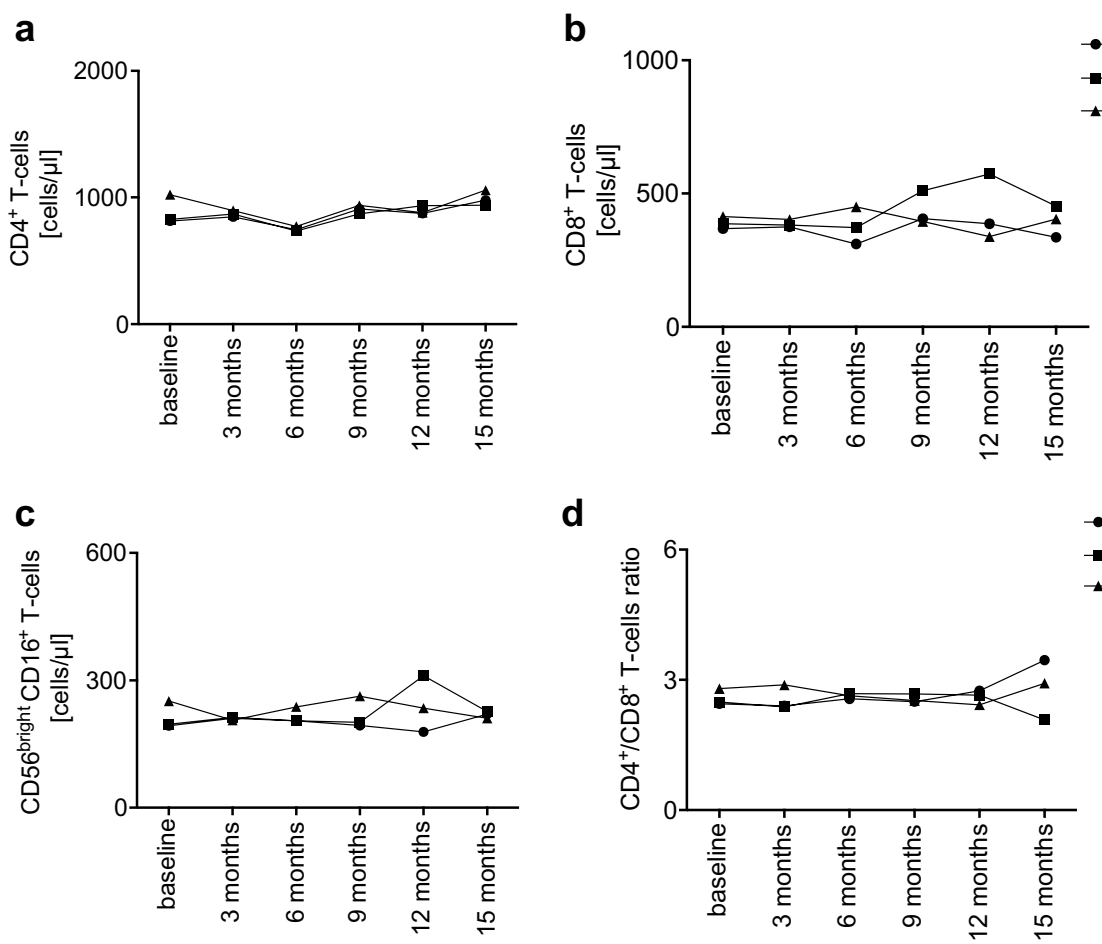

d

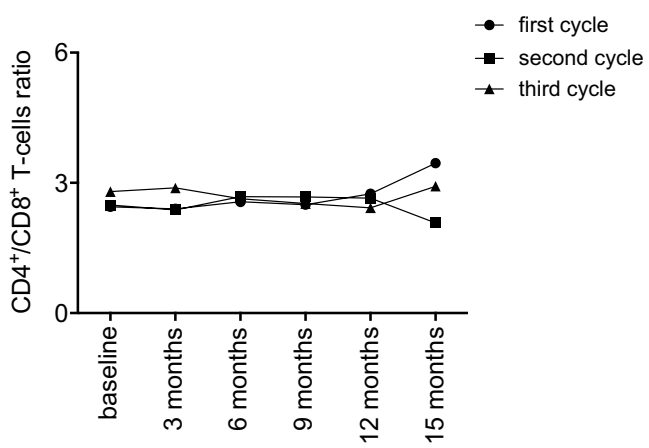

Table 4 Patients' characteristics for NK- and TH1-cells

\begin{tabular}{lcll}
\hline & RTX & RRMS & HC \\
\hline Number of patients & 25 & 25 & 25 \\
Gender (female) & 17 & 16 & 16 \\
Age (years) & $40 \pm 8.7$ & $39 \pm 10$ & $36 \pm 8.2$ \\
Disease duration (years) & $6.4 \pm 5.9$ & $5.3 \pm 4.7$ & \\
\multicolumn{2}{l}{ Treatment at date of analysisRituximab } & DMF & None \\
EDSS at date of analysis & $4.3 \pm 2.9$ & $4.5 \pm 1.9$ & \\
\hline
\end{tabular}

Data are expressed as mean \pm SD where appropriate

$D M F$ dimethyl fumarate, EDSS Expanded Disability Status Scale, $H C$ healthy control, $n$ number of patients, $N M O$ neuromyelitis optica, NMOSD neuromyelitis optica spectrum disease, RRMS relapsingremitting MS, $R T X$ rituximab, SPMS secondary progressive MS

both cerebral and spinal MRI, $\mathrm{Gd}^{+}$lesions remained at low levels during the observation period (Fig. 5b; Table 7).

Due to varying infusion intervals and doses, over time clinical course was analyzed regarding mean annual RTX doses and $\mathrm{CD} 19^{+} \mathrm{B}$-cell at reinfusion/relapse. We did not observe difference in mean RTX dose or CD19+ $\mathrm{B}$-cell counts in regard of EDSS, MRI or clinical relapse (Table 8).

\section{Side effects}

Only major side effects were recorded. One patient was hospitalized for severe pneumonia. In one patient, a reactivation of hepatitis B was observed. In general, there were rare side effects and RTX was well tolerated.

\section{Discussion}

There is growing evidence for the efficacy of B-cell depleting therapies in various autoimmune diseases [4]. This has previously resulted in the FDA approval of RTX for the treatment of rheumatoid arthritis in 2006. Two phase II trials in MS, and several open label trials in MS and NMO/NMOSD underlined the efficacy also in MS and NMO/NMOSD with a favorable safety profile of the anti-CD20 monoclonal antibody RTX. Finally, its successor, the humanized antibody ocrelizumab (Ocrevus ${ }^{\circledR}$, Roche, Switzerland) was recently approved for the treatment of RRMS and PPMS by the FDA and the EMA.

Yet, the RTX dosages used significantly vary in different cohorts, and ocrelizumab is approved only at a defined dosage. Hence, in our study, we evaluated the long-term depletion and repopulation rate of peripheral $\mathrm{CD} 19^{+} \mathrm{B}$-cells under RTX treatment as a potential surrogate marker for the clinical outcome.

We showed that $\mathrm{CD} 19^{+} \mathrm{B}$-cell repopulation was significantly faster when $250 \mathrm{mg}$ RTX was applied. Higher doses of RTX (500-2000 mg) did not lead to sustained B-cell depletion, which might indicate a ceiling effect. Second, long-term RTX treatment did not induce a substantial change in total T-cell populations over time. In a long-term manner, the number of $\mathrm{CD}^{+}{ }^{+}$and $\mathrm{CD} 8^{+}$-cells, as well as CD4/CD8 ratio did not change significantly compared to pre-RTX levels. This is well in line with previous studies [13]. We did not observe any severe side effects such as 

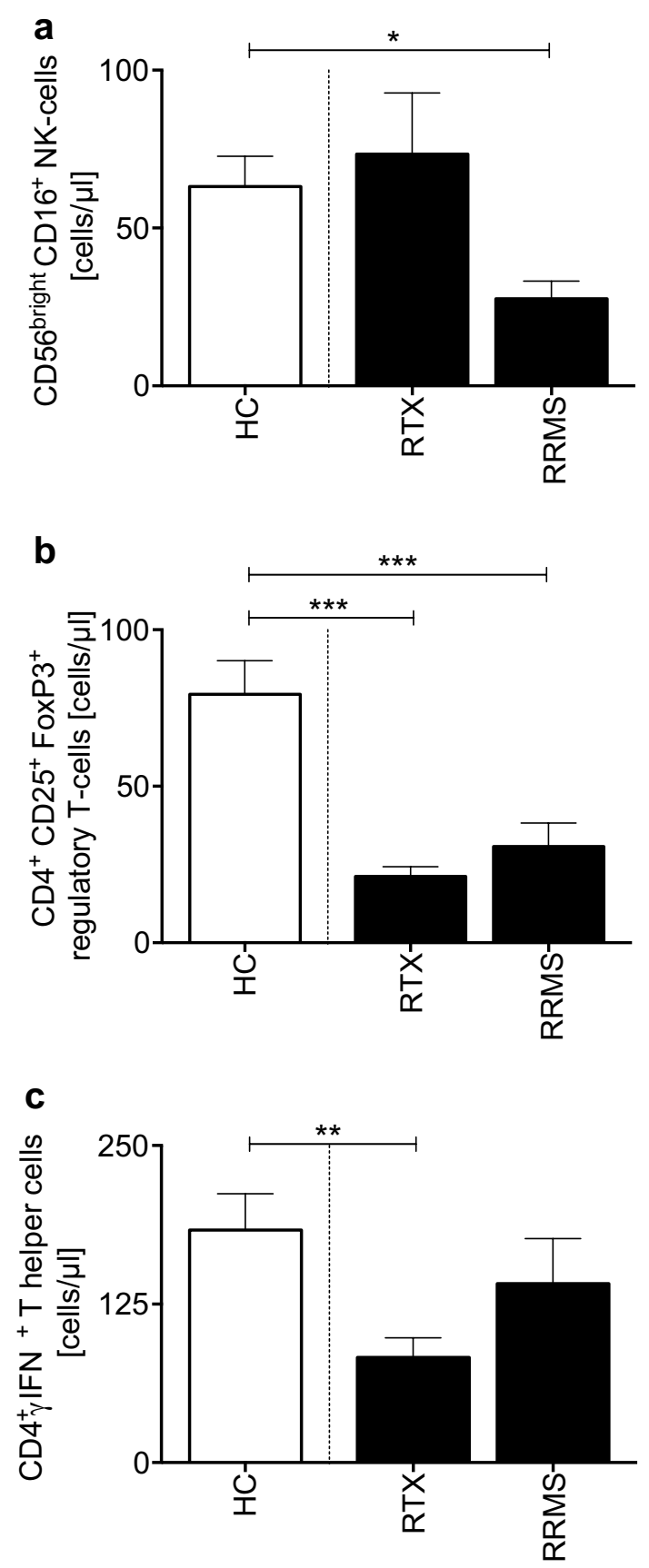

Fig. 4 a Natural killer- (NK-) cells $\left(\mathrm{CD} 56^{\text {bright }} \mathrm{CD} 16^{+}\right)$and T helper -cell subsets in rituximab (RTX) treated MS vs. RRMS without RTX, and healthy controls [4]. b Regulatory T-cells $\left(\mathrm{CD} 4{ }^{+} \mathrm{CD} 25^{+} \mathrm{FoxP}^{+}\right)$, c Th1-cells $\left(\mathrm{CD} 4^{+}\right.$IFN $\left.\gamma^{+}\right)$

secondary autoimmunity (SAI). This is in contrast to T- and B-cell-depleting therapies, i.e. alemtuzumab, where SAI are seen in more than $30 \%$. These side effects are attributed to an excessive repopulation of $\mathrm{B}$ cells accompanied by the depletion of (regulatory) T-cells [1,5].

Moreover, reduced numbers of CD19+ $\mathrm{B}$-cells were associated with reduced ARR, EDSS and reduced numbers of
Table 5 Disease course and previous treatment

\begin{tabular}{lll}
\hline Disease course & $n(\%)$ & Mean \pm SD \\
\hline EDSS & & \\
$\quad$ Baseline & $153(100)$ & $4.5 \pm 2.2$ \\
12 months & $152(96.8)$ & $4.5 \pm 2.3$ \\
24 months & $101(64.3)$ & $4.3 \pm 2.2$ \\
36 months & $77(49.0)$ & $4.1 \pm 2.2$ \\
ARR in RRMS and SPMS PE & 98 & $1.55 \pm 1.36$ \\
ARR in RRMS and SPMS AE & & $0.26 \pm 0.52$ \\
ARR in NMO/NMOSD PE & 21 & $2.22 \pm 1.89$ \\
ARR in NMO/NMOSD AE & & $0.42 \pm 0.56$ \\
Time to first relapse (observed & 20 & $5.35 \pm 3.05$ \\
relapses; months) & & \\
\hline
\end{tabular}

$A E$ after enrollment [ARR after enrollment was over whole follow-up period (mean $2.19 \pm 1.75$ years)], ARR annualized relapse rate, EDSS Expanded Disability Status Scale, $n$ number of available patient data, $N M O$ neuromyelitis optica NMOSD neuromyelitis optica spectrum disease, $P E$ prior to enrollment (ARR prior to enrollment was over 2 years), RRMS relapsing-remitting MS, SPMS secondary progressive MS, RRMS relapsing remitting data are expressed as mean $\pm \mathrm{SD}$ where appropriate

$\mathrm{Gd}^{+}$enhancing lesions. Besides the small number and different treatment regimens, NMO/NMOSD and MS patients did neither show significant differences in intensity, nor duration of cell depletion.

Continuous monitoring of $\mathrm{CD} 19^{+} \mathrm{B}$-cells may be a sufficient tool for an individualized decision making on dosage and reinfusion intervals of B-cell depleting therapies. Fixed dosage and infusion intervals, as in therapy regime of ocrelizumab, may explain the increased risk for infections and malignancies. In our cohort, dosage of RTX ranging 500-1000 mg led to longer reinfusion intervals. Higher dosages of RTX neither lead to extended reapplication intervals, nor any additional treatment effects, and may be avoided [16].

Despite the therapeutic effect being closely associated with the absence of $\mathrm{CD} 19^{+} \mathrm{B}$-cells, we did not observe a correlation between B-cell counts at the time-point of reinfusion and clinical course or MRI outcome in patients in whom relapses did occur. This might be due to different proportion of progenitor $\mathrm{CD} 19^{+} \mathrm{B}$-cells and mature B-cells after the first cycle of RTX treatment. After replenishment of the B-cell compartment there are mainly naïve B-cells following repletion of circulating B-cells. $\mathrm{CD} 27^{+}$memory phenotype cells stay at significantly lower levels in peripheral blood [13]. It has been recently shown that memory B cells drive proliferation of self-reactive brain-homing $\mathrm{CD} 4^{+} \mathrm{T}$-cells in patients with multiple sclerosis and that RTX strongly reduces autoproliferation and proinflammatory cytokine responses [10]. This may be one of the reasons for the longlasting beneficial clinical effects of anti-CD20 therapy [13, 15]. However, B-cell responses in MS patients have shown 
Table 6 Stratification of EDSS outcome

\begin{tabular}{llll}
\hline EDSS compared to baseline & RRMS $n(\%)$ & SPMS $n(\%)$ & NMO/NMOSD $n(\%)$ \\
\hline Available scores after 12 months & $66\left(p^{* * *} \leq 0.001\right)$ & $60\left(p^{* * *} \leq 0.001\right)$ & $21\left(p^{* * *} \leq 0.001\right)$ \\
EDSS decreased & $25(38)$ & $7(12)$ & $6(29)$ \\
EDDS stable & $31(47)$ & $42(70)$ & $12(57)$ \\
EDSS increased & $10(15)$ & $11(18)$ & $3(14)$ \\
Available scores after 24 months & $46\left(p^{* * *} \leq 0.001\right)$ & $39\left(p^{* * *} \leq 0.001\right)$ & $15(\mathrm{n} . \mathrm{s})$. \\
EDSS decreased & $17(37)$ & $4(10)$ & $4(17)$ \\
EDDS stable & $21(46)$ & $23(59)$ & $6(40)$ \\
EDSS increased & $8(17)$ & $12(31)$ & $5(33)$ \\
Available scores after 36 months & $38\left(p^{* * *} \leq 0.001\right)$ & $29\left(p^{* *} \leq 0.01\right)$ & $10(\mathrm{n} . \mathrm{s})$. \\
EDSS decreased & $14(37)$ & $7(24)$ & $2(20)$ \\
EDDS stable & $17(45)$ & $13(45)$ & $4(40)$ \\
EDSS increased & $7(18)$ & $9(31)$ & $4(40)$ \\
\hline
\end{tabular}

The percentage refers to the total number of patients of one subtype at the indicated time point

EDSS Expanded Disability Status Scale, $n$ number of patients, $N A$ data not available, $N M O$ neuromyelitis optica, NMOSD neuromyelitis optica spectrum disease, RRMS relapsing-remitting MS, SPMS secondary progressive MS

$p$ value refers to number of patients with stable disease (=EDDS decreased or stable) and patients with increased EDSS according to course of MS (RRMS, SPMS) or NMO/NMOSD

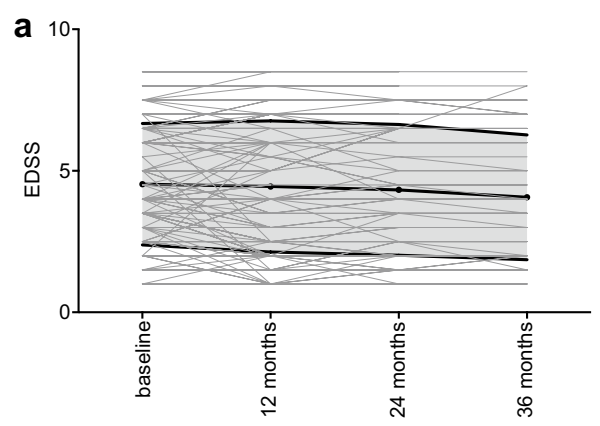

b

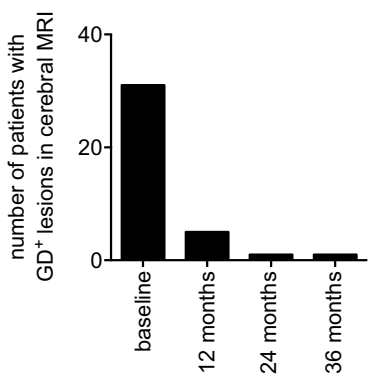

C

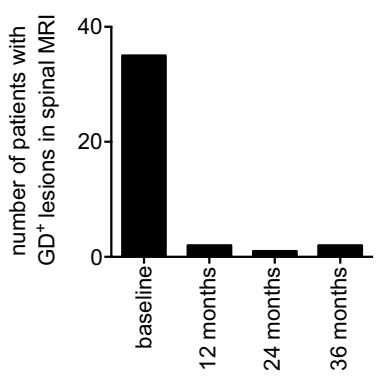

Fig. 5 a Disability course as measured by EDSS over 36 months. EDSS Extended Disability Status Scale. Black line represents mean and SD. Lines in light gray show connecting line between individual replicated values. b, $\mathbf{c} G d^{+}$gadolinium-enhancing lesions. Absolute number of patients with $\mathrm{Gd}^{+} \mathrm{T} 1$ lesions in cerebral (b) and cervical spinal cord (c) MRI

to be per se altered in MS [3]. We observed an increase of B cells over time that is due to statistical effects and patients' behavior. Number of patients being analyzed decreased over time and simultaneously variations in $\mathrm{CD} 19^{+} \mathrm{B}$-cell counts increased as there were single statistical outliers.

Our study has several limitations, the main being its retrospective character. Another limitation arises from the different dosages used over time. The varying infusion protocols reflect the evolution of RTX titration toward lower dosage over the past 10 years in off-label use, and allow the differentiated analysis of B-cell repopulation rates.

Nevertheless, we could build up a robust database over a long-term period of 100 months with a sufficiently large number of patients. Theoretically, other immune cell subsets bearing CD20 antigen may contribute to the efficacy of RTX and may be overlooked in FACS analysis-guided infusion cycles. At least, in our cohort, the clinical effect was very robust.

In summary, in contrast to treatment of rheumatoid arthritis or lymphoma, $500 \mathrm{mg}$ or even $250 \mathrm{mg}$ RTX in intervals of approximately 6-9 months are an effective and at the same time safe therapy option in MS. In our cohort, higher dosage in elongated intervals proved equally effective. However, dosages beyond $1000 \mathrm{mg}$ did not reveal additional effects in regard to B-cell depletion, administration interval and clinical outcome. Given the large inter-individual range of B-cell recovery time, we suggest that the $\mathrm{CD} 19^{+} \mathrm{B}$-cell repopulation rate may serve as surrogate marker to appraise individually adapted therapy intervals. Although the next generation of anti-CD20 monoclonal antibodies is approved for the treatment of MS, many mechanistic aspects and longterm immunological consequences remain unclear. Analysis of more than 10 years of RTX use in MS may shed further light into these questions. 
Table 7 MRI data

\begin{tabular}{lllll}
\hline MRI & $\begin{array}{l}\text { Total } n=(\text { avail- } \\
\text { able scans })\end{array}$ & RRMS & SPMS & NMO/NMOSD \\
\hline Cerebral T2 lesions & & & & \\
Baseline & $(150)$ & $(76)$ & $(57)$ & $(17)$ \\
New lesions within 1st year & $18(137)$ & $6(68)$ & $8(51)$ & $4(18)$ \\
New lesions within 2nd year & $6(105)$ & $3(46)$ & $2(42)$ & $1(17)$ \\
New lesions within 3rd year & $6(74)$ & $3(34)$ & $3(29)$ & $0(11)$ \\
Cerebral Gd ${ }^{+}$lesions & & & & \\
Baseline & $31(150)$ & $24(76)$ & $6(57)$ & $1(17)$ \\
New Gd ${ }^{+}$lesions within 1st year & $5(136)$ & $3(68)$ & $2(51)$ & $0(18)$ \\
New Gd ${ }^{+}$lesions within 2nd year & $1(103)$ & $0(46)$ & $1(42)$ & $0(17)$ \\
New Gd ${ }^{+}$lesions within 3rd year & $1(72)$ & $1(34)$ & $0(29)$ & $0(11)$ \\
Cervical T2 lesions & & & & \\
Baseline & $(141)$ & $(66)$ & $(54)$ & $(21)$ \\
New lesions within 1st year & $4(130)$ & $1(62)$ & $1(50)$ & $1(18)$ \\
New lesions within 2nd year & $3(100)$ & $2(46)$ & $1(39)$ & $0(15)$ \\
New lesions within 3rd year & $3(74)$ & $0(34)$ & $1(29)$ & $0(11)$ \\
Cervical Gd ${ }^{+}$lesions & & & & \\
Baseline & $35(72)$ & $16(66)$ & $10(54)$ & $9(21)$ \\
New Gd ${ }^{+}$lesions within 1st year & $2(127)$ & $0(62)$ & $0(50)$ & $2(18)$ \\
New Gd ${ }^{+}$lesions within 2nd year & $1(99)$ & $0(46)$ & $0(39)$ & $1(15)$ \\
New Gd ${ }^{+}$lesions within 3rd year & $2(74)$ & $1(34)$ & $0(29)$ & $1(11)$ \\
\hline
\end{tabular}

$G d^{+}$gadolinium enhancing, $n$ indicates the total number of patients with new lesions compared to previously available MRI. T2 and $\mathrm{Gd}^{+}$lesions were counted separately, NMO neuromyelitis optica, NMOSD neuromyelitis optica spectrum disease, $R R M S$ relapsing-remitting MS, SPMS secondary progressive MS

Table 8 Clinical course according to dosage/interval

\begin{tabular}{|c|c|c|c|c|c|c|c|c|}
\hline & \multicolumn{4}{|c|}{ Mean annual RTX dose $(\mathrm{mg} \pm \mathrm{SD})$} & \multicolumn{4}{|c|}{$\begin{array}{l}\mathrm{CD} 19^{+} \text {B-cell counts at reinfusion/relapse } \\
\text { when applicable }(\text { cells } / \mu 1 \pm \mathrm{SD})\end{array}$} \\
\hline & All patients & RRMS & SPMS & NMO/NMOSD & All patients & RRMS & SPMS & NMO \\
\hline EDSS stable & $1212 \pm 793$ & $1174 \pm 787$ & $1019 \pm 770$ & $1954 \pm 838$ & $70 \pm 77$ & $71 \pm 72$ & $91 \pm 94$ & $45 \pm 81$ \\
\hline EDSS worsened & $1139 \pm 702$ & $1444 \pm 1077$ & $1071 \pm 710$ & $1822 \pm 1114$ & $67 \pm 66$ & $88 \pm 86$ & $57 \pm 68$ & $82 \pm 81$ \\
\hline$p$ value & 0.77 & 0.57 & 0.42 & 0.59 & 0.99 & 0.52 & 0.12 & 0.19 \\
\hline MRI stable & $1257 \pm 846$ & $1260 \pm 817$ & $1009 \pm 744$ & $1784 \pm 885$ & $73 \pm 79$ & $84 \pm 81$ & $61 \pm 67$ & $56 \pm 96$ \\
\hline MRI progression & $1168 \pm 928$ & $984 \pm 891$ & $983 \pm 848$ & $1842 \pm 767$ & $65 \pm 77$ & $46 \pm 41$ & $99 \pm 108$ & $57 \pm 76$ \\
\hline$p$ value & 0.39 & 0.14 & 0.51 & 0.67 & 0.48 & 0.08 & 0.49 & 0.67 \\
\hline Patients without clinical relapse & $1284 \pm 864$ & $1148 \pm 815$ & $1022 \pm 702$ & $1727 \pm 804$ & $70 \pm 79$ & $80 \pm 80$ & $63 \pm 67$ & $47 \pm 86$ \\
\hline Patients with clinical relapse & $1430 \pm 947$ & $1411 \pm 924$ & $1374 \pm 1092$ & $1986 \pm 863$ & $74 \pm 80$ & $62 \pm 56$ & $83 \pm 94$ & $75 \pm 76$ \\
\hline$p$ value & 0.46 & 0.33 & 0.54 & 0.59 & 0.76 & 0.46 & 0.96 & 0.27 \\
\hline
\end{tabular}

Mean annual RTX dose = mean dose applied between the recorded variables (EDSS, MRI) during whole follow-up. MRI progression designates all new gadolinium-enhancing or new T2 lesions compared to previous MRI (cerebral and spinal) during whole follow-up

For patients with a relapsed $\mathrm{CD} 19^{+} \mathrm{B}$-cell count indicates the first analysis/cell count after relapse and before re-dosing. For patients without a relapse, it is defined as highest available cell count before re-dosing

Data are expressed as mean \pm SD where appropriate

EDSS Expanded Disability Status Scale, NMO neuromyelitis optica, NMOSD neuromyelitis optica spectrum disease, $R T X$ rituximab, $R R M S$ relapsing-remitting MS, SPMS secondary progressive MS 


\section{Compliance with ethical standards}

Conflicts of interest JB, MP and AD declare that there is no conflict of interest. GE has received speaker honoraria from Biogen, Teva, Novartis, Bayer, Almirall and Merck Serono. She has received grant support from Biogen and TEVA. KH has served on scientific advisory board for Bayer, Biogen, Sanofi, Teva, Roche, Novartis, Merck Serono. She has received speaker honoraria and research support from Bayer, Biogen, Merck Serono, Novartis, Sanofi, Genzyme, Teva. KH received support for congress participation from Bayer, Biogen, Genzyme, Teva, Roche and Merck Serono. DHL has received travel grants or speaker honoraria from Bayer, Biogen, Merck Serono, Novartis, and TEVA. RAL received compensation for activities with Bayer, Biogen, Celgene, Genzyme, Merck, Novartis, Roche, and TEVA as well as research support from Biogen and Novartis. RAL holds an endowed professorship sponsored by Novartis Pharma. AH received speaker honoraria from Biogen, Teva, Novartis, Bayer and Merck. RG received speaker and board honoraria from Baxter, Bayer Schering, Biogen, CLB Behring, Genzyme, Merck Serono, Novartis, Stendhal, Talecris, TEVA. His department received grant support from Bayer Schering, Biogen, Genzyme, Merck Serono, Novartis, and TEVA.

Open Access This article is distributed under the terms of the Creative Commons Attribution 4.0 International License (http://creativeco mmons.org/licenses/by/4.0/), which permits unrestricted use, distribution, and reproduction in any medium, provided you give appropriate credit to the original author(s) and the source, provide a link to the Creative Commons license, and indicate if changes were made.

\section{References}

1. Baker D, Herrod SS, Alvarez-Gonzalez C, Zalewski L, Albor C, Schmierer K (2017) Both cladribine and alemtuzumab may effect MS via B-cell depletion. Neurol Neuroimmunol Neuroinflamm 4:e360

2. Bar-Or A, Calabresi PA, Arnold D, Markowitz C, Shafer S, Kasper LH, Waubant E, Gazda S, Fox RJ, Panzara M, Sarkar N, Agarwal S, Smith CH (2008) Rituximab in relapsing-remitting multiple sclerosis: a 72-week, open-label, phase I trial. Ann Neurol 63:395-400

3. Bar-Or A, Fawaz L, Fan B, Darlington PJ, Rieger A, Ghorayeb C, Calabresi PA, Waubant E, Hauser SL, Zhang J, Smith CH (2010) Abnormal B-cell cytokine responses a trigger of T-cell-mediated disease in MS? Ann Neurol 67:452-461

4. Casan JML, Wong J, Northcott MJ, Opat S (2018) Anti-CD20 monoclonal antibodies: reviewing a revolution. Hum Vaccine Immunother 10:1-22

5. Haghikia A, Dendrou CA, Schneider R, Gruter T, Postert T, Matzke M, Stephanik H, Fugger L, Gold R (2017) Severe B-cellmediated CNS disease secondary to alemtuzumab therapy. Lancet Neurol 16:104-106

6. Haghikia A, Hohlfeld R, Gold R, Fugger L (2013) Therapies for multiple sclerosis: translational achievements and outstanding needs. Trends Mol Med 19:309-319

7. Hauser SL, Bar-Or A, Comi G, Giovannoni G, Hartung HP, Hemmer B, Lublin F, Montalban X, Rammohan KW, Selmaj K,
Traboulsee A, Wolinsky JS, Arnold DL, Klingelschmitt G, Masterman D, Fontoura P, Belachew S, Chin P, Mairon N, Garren H, Kappos L, Opera I, Investigators OIC (2017) Ocrelizumab versus interferon beta-1a in relapsing multiple sclerosis. N Engl J Med 376:221-234

8. Hauser SL, Waubant E, Arnold DL, Vollmer T, Antel J, Fox RJ, Bar-Or A, Panzara M, Sarkar N, Agarwal S, Langer-Gould A, Smith CH, Group HT (2008) B-cell depletion with rituximab in relapsing-remitting multiple sclerosis. N Engl J Med 358:676-688

9. Hawker K, O'Connor P, Freedman MS, Calabresi PA, Antel J, Simon J, Hauser S, Waubant E, Vollmer T, Panitch H, Zhang J, Chin P, Smith CH, Group OT (2009) Rituximab in patients with primary progressive multiple sclerosis: results of a randomized double-blind placebo-controlled multicenter trial. Ann Neurol 66:460-471

10. Jelcic I, Al Nimer F, Wang J, Lentsch V, Planas R, Jelcic I, Madjovski A, Ruhrmann S, Faigle W, Frauenknecht K, Pinilla C, Santos R, Hammer C, Ortiz Y, Opitz L, Gronlund H, Rogler G, Boyman O, Reynolds R, Lutterotti A, Khademi M, Olsson T, Piehl F, Sospedra M, Martin R (2018) Memory B cells activate brainhoming, autoreactive CD4(+) T cells in multiple sclerosis. Cell 175:85-100

11. Montalban X, Belachew S, Wolinsky JS (2017) Ocrelizumab in primary progressive and relapsing multiple sclerosis. N Engl J Med 376:1694

12. Nikoo Z, Badihian S, Shaygannejad V, Asgari N, Ashtari F (2017) Comparison of the efficacy of azathioprine and rituximab in neuromyelitis optica spectrum disorder: a randomized clinical trial. J Neurol 264:2003-2009

13. Palanichamy A, Jahn S, Nickles D, Derstine M, Abounasr A, Hauser SL, Baranzini SE, Leppert D, von Budingen HC (2014) Rituximab efficiently depletes increased CD20-expressing T cells in multiple sclerosis patients. J Immunol 193:580-586

14. Polman CH, Reingold SC, Edan G, Filippi M, Hartung HP, Kappos L, Lublin FD, Metz LM, McFarland HF, O'Connor PW, Sandberg-Wollheim M, Thompson AJ, Weinshenker BG, Wolinsky JS (2005) Diagnostic criteria for multiple sclerosis: 2005 revisions to the "McDonald Criteria". Ann Neurol 58:840-846

15. Reff M, Carner K, Chambers K, Chinn P, Leonard J, Raab R, Newman R, Hanna N, Anderson D (2017) Depletion of B cells in vivo by a chimeric mouse human monoclonal antibody to CD20. http:// www.bloodjournal.org/content/bloodjournal/83/2/435.full.pdf. Accessed 3 Nov 2017

16. Salzer J, Svenningsson R, Alping P, Novakova L, Bjorck A, Fink K, Islam-Jakobsson P, Malmestrom C, Axelsson M, Vagberg M, Sundstrom P, Lycke J, Piehl F, Svenningsson A (2016) Rituximab in multiple sclerosis: a retrospective observational study on safety and efficacy. Neurology 87:2074-2081

17. Spelman T, Frisell T, Piehl F, Hillert J (2017) Comparative effectiveness of rituximab relative to IFN-beta or glatiramer acetate in relapsing-remitting MS from the Swedish MS registry. Mult Scler 24(8):1087-1095

18. Wekerle H (2017) B cells in multiple sclerosis. Autoimmunity 50:57-60

19. Wingerchuk DM, Lennon VA, Pittock SJ, Lucchinetti CF, Weinshenker BG (2006) Revised diagnostic criteria for neuromyelitis optica. Neurology 66:1485-1489 